\title{
Th2 mediated regulation in RA and the spondyloarthropathies
}

\section{J A G van Roon, J W J Biilsma}

\section{Can atopy help to clarify the role of Th2 mediated regulation} in these diseases?

A mongst the heterogeneity of human immune responses $\mathrm{T}$ helper $(\mathrm{Th})$ lymphocyte subsets have been shown to have an important role. ${ }^{1}$ Of these different subsets, Thl cells mediate cellular immunity, including cytotoxicity and delayed-type hypersensitivity responses through the specific production of interferon $\gamma(\mathrm{IFN} \gamma)$ and interleukin (IL) 2 . Th2 cells, characterised by IL4, IL5, and IL13 production, favour humoral immunity and down regulate Thl mediated cellular immunity. Th2 responses are associated with IL4/IL13 mediated IgE production and IL5 mediated eosinophilia. Thl activity in its turn inhibits these responses and results in effective immune responses against several infectious agents such as bacteria and viruses. Also, in several autoimmune diseases Thl cells contribute to the induction and persistence of inflammation and inflammation-induced tissue damage.

Numerous studies have shown that Thl-induced immunity is inhibited by suppressive Th cells other than IL $4^{+}$Th2 cells. These suppressive cells are also distinguished by their particular cytokine secretion and/or function: transforming growth factor $\beta$ (TGF $\beta)^{+}$Th3 cells, IL10 $\mathrm{T}$ regulatory $\mathrm{l}(\operatorname{Tr} \mathrm{l})$ cells, and $\mathrm{CD} 4{ }^{+} \mathrm{CD} 25^{+}$anergic/suppressive cells. ${ }^{23}$ Although all these subsets may contribute to suppression of Thl activity, the balance between Th1 and Th2 cells has been shown to strongly influence many inflammatory responses. Owing to the mutually antagonising abilities of Thl and Th2 cells in many experimental animal and human in vitro studies, the Thl/ Th2 balance in rheumatoid arthritis (RA) has been extensively studied.

\section{"Balance between Th 1 and Th2 cells strongly influences inflammatory responses"}

\section{Th1 predominance in RA and the impact of atopy-induced Th2 responses}

In RA synovial tissue, synovial fluid, and serum, analysis of IFN $\gamma$ and IL4 production to indicate Th1 and Th2 activity, showed that Thl activity was clearly predominant and Th2 activity was absent compared with control subjects (table

Table 1 Cytokine profiles in rheumatoid arthritis and the spondyloarthropathies

\begin{tabular}{|c|c|c|c|c|c|c|}
\hline & $\mathrm{IFN} \gamma$ & IL4 & IL10 & TNF $\alpha$ & IL1 $\beta$ & IL6 \\
\hline \multicolumn{7}{|c|}{ Cytokine analysis in biological fluids and tissue } \\
\hline \multicolumn{7}{|c|}{ Serum* ${ }^{*}$} \\
\hline RA & + & & & ++ & ++ & ++ \\
\hline AS & 0 & & & + & 0 & + \\
\hline $\operatorname{ReA}$ & 0 & 0 & & 0 & 0 & 0 \\
\hline \multicolumn{7}{|c|}{ Synovial fluid* } \\
\hline RA & + & 0 & & ++ & ++ & ++ \\
\hline AS & & & & & & \\
\hline $\operatorname{ReA}$ & + & & ++ & + & 0 & ++ \\
\hline \multicolumn{7}{|c|}{ Synovial tissue $†$} \\
\hline RA & + & 0 & + & +++ & ++ & +++ \\
\hline AS & & & & ++ & 0 & \\
\hline $\operatorname{ReA}$ & + & + & + & & & \\
\hline \multicolumn{7}{|c|}{$\begin{array}{l}T \text { cell cytokine analysis } \\
\text { Peripheral blood* }\end{array}$} \\
\hline RA & - & $0 /+$ & + & - & & \\
\hline AS & - & 0 & + & - & & \\
\hline $\operatorname{ReA}$ & - & 0 & - & - & & \\
\hline
\end{tabular}

Assessed by ELISA* or immunohistochemistry/in situ hybridisation $\uparrow$. T cell cytokine analysis (by ELISA/FACS) is done after short term in vitro culture of T cells $\ddagger$. Increased $(+,++,+++)$, decreased $(-,-)$ or equal $(0)$ cytokine expression levels compared with control subjects are indicated. The summary in this table is based on references $4-6,17-24,29$ and 33 among others.

1). ${ }^{4-6}$ The Thl/Th2 imbalance in RA joints is associated with high numbers of activated macrophages, leading to an aggressive form of arthritis with rapidly occurring joint destruction. ${ }^{7}$ Based on the pivotal role of the Thl predominance in RA it has been suggested that patients with RA will benefit from Th2 activity. Until now, treatments aimed at enhancing or mimicking Th2 activity-for example, through IL4 or IL10, have not provided evidence for this hypothesis. ${ }^{8}$ However, the naturally occurring mutual antagonism of atopy and RA supports this hypothesis and indicates the role of Th1/Th2 balance in RA.

\section{"RA is associated with a} $40-50 \%$ reduction in atopic disorders"

The prevalence of RA, in which Thl predominates, was found to have a favourable impact on several atopic disorders known to be associated with a clear Th2 predominance (table 2). In five European studies RA was associated on average with a $40-50 \%$ reduction in the prevalence of atopic disorders. ${ }^{9-13}$ In one study which evaluated a limited number of patients with RA $(n=40)$ atopy assessment by a health assessment questionnaire did not show a decreased prevalence. ${ }^{10}$ However, when allergen skin prick tests were performed to confirm atopy, a decrease of $45 \%$ in patients with positive tests was found among patients with RA compared with healthy controls. ${ }^{10}$ Similarly, in another study where hay fever was confirmed by this test, a 50\% reduction in patients with RA compared with non-RA controls was seen. ${ }^{12}$ Furthermore, this was associated with a reduction of serum IgE levels and eosinophilia, further indicating suppressed Th2 responses.

In addition to the inhibition of Th2 mediated immunity by Thl cells, in hay fever/patients with RA reduced Thl activity (IFN $\gamma$ production) was seen compared with patients with RA with no hay fever (table 2). This Thl reduction was associated with reduced disease activity as measured by reduced acute phase responses and joint scores for inflammation and joint destruction. In agreement with this, Rudwaleit et al reports in this issue of the Annals that atopic patients whose atopy started before their RA developed have a reduced disease severity. ${ }^{13}$

In support of the mutual antagonism of Thl mediated autoimmune diseases and atopy other studies have shown that both patients with multiple sclerosis and type I diabetes (Thl driven diseases) had decreased prevalence and fewer symptoms of IgE mediated allergic diseases (table 2)..$^{14}$ Furthermore, an inverse 
Table 2 Mutual antagonism of atopy and inflammatory conditions

\begin{tabular}{|c|c|c|c|c|c|c|c|c|c|}
\hline \multirow[b]{3}{*}{$\begin{array}{l}\text { Inflammatory } \\
\text { condition }\end{array}$} & \multirow[b]{3}{*}{$\begin{array}{l}\text { Dominant Th } \\
\text { response }\end{array}$} & \multirow[b]{3}{*}{$\begin{array}{l}\text { Controls/ } \\
\text { inflam. (n) }\end{array}$} & \multicolumn{6}{|c|}{ Prevalence of atopic disorders } & \multirow[b]{3}{*}{ Ref } \\
\hline & & & \multicolumn{3}{|c|}{ Questionnaire (\% positive) } & \multicolumn{3}{|c|}{ Allergy test (\% positive) } & \\
\hline & & & Control & Inflam. & $\begin{array}{l}\text { Difference } \\
(\%)\end{array}$ & Control & Inflam. & $\begin{array}{l}\text { Difference } \\
(\%)\end{array}$ & \\
\hline \multicolumn{10}{|c|}{ Impact of inflammatory conditions on atopy } \\
\hline RA & Thl 1 & $40 / 40$ & 35 & 35 & 0 & 22.5 & 12.5 & $-45^{*}$ & 10 \\
\hline RA & Thl 1 & $339 / 304$ & 30 & 20 & -33 & 8 & 4 & $-50 \dagger \ddagger$ & 12 \\
\hline RA & Thl 1 & $173 / 173$ & 18.8 & 7.5 & -60 & & & & 9 \\
\hline RA & Thl 1 & $248 / 102$ & 21.9 & 14.7 & -33 & & & & 11 \\
\hline RA & Thl 1 & $536 / 487$ & 20.7 & 13.1 & -37 & & & & 13 \\
\hline AS & Th? & $536 / 248$ & 20.7 & 24.6 & +19 & & & & 13 \\
\hline Type 1 diabetes & Thl 1 & $? / 157$ & 51 & 27 & -48 & & & & 14 \\
\hline & Thl 1 & $18 / 24$ & & & & 50 & 21 & $-58 \dagger$ & 15 \\
\hline Tuberculin reactivity & Thl 1 & $290 / 213$ & 46.8 & 25.8 & -45 & 55.8 & 41.8 & $-25 \dagger$ & 16 \\
\hline $\begin{array}{l}\text { Inflammatory } \\
\text { condition }\end{array}$ & $\begin{array}{l}\text { Dominant Th } \\
\text { response }\end{array}$ & \multicolumn{7}{|c|}{ Inhibited/stimulated disease characteristics (\%) } & Ref \\
\hline \multicolumn{10}{|c|}{ Impact of atopy on inflammatory conditions } \\
\hline \multirow[t]{4}{*}{ RA } & Thl & \multirow{2}{*}{\multicolumn{2}{|c|}{$\begin{array}{l}\text { Acute phase responses } \\
\text { Joint inflammation }\end{array}$}} & - & & & & & 12 \\
\hline & & & & - & & & & & \\
\hline & & \multirow{2}{*}{\multicolumn{2}{|c|}{$\begin{array}{l}\text { Joint destruction } \\
\text { Thl cytokine production }\end{array}$}} & - & & & & & \\
\hline & & & & - & & & & & \\
\hline RA & Thl 1 & \multicolumn{2}{|c|}{ Disease severity score } & - & & & & & 13 \\
\hline AS & Th? & \multicolumn{2}{|c|}{ Disease severity score } & + & & & & & 13 \\
\hline Tuberculin. reactivity & Thl & \multirow{2}{*}{\multicolumn{2}{|c|}{$\begin{array}{l}\text { DTH responses } \\
\text { Thl cytokine production }\end{array}$}} & - & & & & & 16 \\
\hline & & & & - & & & & & \\
\hline
\end{tabular}

association was observed between tuberculin-induced inflammatory responses and atopic disorders which were related to the mutual inhibition of Thl (IFN $\gamma$, IL12) and Th2 mediated (IL4, IL10 and IL13) immunity (table 2) ${ }^{16}$ In the latter study it was shown that the balance between these responses changed over time, indicating that environmental factors influence the Th1/Th2 balance in genetically predisposed subjects.

The abovementioned studies support the assumption that several autoimmune diseases, including RA, might benefit from Th2 mediated immune deviation. Therefore, studying the impact of well defined Th2 mediated diseases on arthritic conditions may help to clarify the role of this immune response in regulation of disease activity. Thus, Rudwaleit et al investigated the impact of atopic disorders on the seronegative spondyloarthropathy ankylosing spondylitis (AS). ${ }^{13}$ Additionally, the reverse-the effects of this disease on atopic disorders-was also studied.

\section{Th1/Th2 balance in AS and atopy-induced Th2 responses}

The seronegative spondyloarthropathies include a heterogeneous group of diseases characterised by inflammatory axial spine disease, asymmetric peripheral arthritis, enthesopathy, inflammatory eye disease, and overlapping mucocutaneous features occurring in the absence of serum rheumatoid factor. In adults this group of diseases includes AS, reactive arthritis (ReA), some forms of psoriatic arthritis (PsA), undifferentiated forms of spondyloarthropathy (uSpA), and arthropathies accompanying inflammatory bowel disease. These arthropathies share features with RA, such as inflammation of the peripheral joints. To specifically intervene in these arthritides it is important to define systemic and intra-articular immune responses. Several studies have defined these responses in AS to a certain extent.

The profile of circulating proinflammatory cytokines in AS has similarities with RA but differs in some aspects (table 1). Serum levels of TNF $\alpha$ and IL6 in AS are increased compared with controls, although cytokine levels are generally lower than in patients with RA. ${ }^{5}$ Increased TNF $\alpha$ production was also found in the synovial tissue of patients with AS. ${ }^{17}$ In contrast with RA, ILI $\beta$ was not increased in AS serum and synovial tissue. ${ }^{5}{ }^{17}$ IFN $\gamma$, also in contrast with RA, could not be detected in the serum of patients with AS. ${ }^{5}$

Although a large number of studies have confirmed the Th1/Th2 imbalance in RA, only a few studies have focused on Th cytokine profiles in AS. Cytokine profiles of circulating T cells in AS are similar to those found in patients with RA (table 1). Both in patients with RA and those with AS, decreased peripheral IFN $\gamma$ and TNF $\alpha$ production by T cells is observed, whereas unchanged and even increased IL4 production is documented. ${ }^{18-21}$ Similar observations were made in patients with ReA and seem to hold true for PsA and uSpA.22 23 Analysis of peripheral $\mathrm{T}$ cell cytokine profiles might be helpful but should be interpreted with caution. For example, reduced peripheral Thl activity and TNF $\alpha$ production in patients with RA and ReA are associated with increased local production of these cytokines during active disease (table 1). ${ }^{462324}$ Furthermore, reduced peripheral $\mathrm{T}$ cell cytokine secretion is at least partly a consequence of the strong ability of activated Thl cells to migrate to sites of inflammation. ${ }^{2125} 26$ This is associated with high antigen reactivity at sites of inflammation and low antigen reactivity in the peripheral blood of patients with RA, AS, and ReA. ${ }^{24} 27$ Therefore, the reduced peripheral Thl activity in patients with AS, as well as in other spondyloarthropathies, cannot be considered as evidence for local impaired Thl cytokine production. This is supported by the reduction in TNF $\alpha$ secretion by peripheral T cells in AS, observed to be associated with increased TNF $\alpha$ production in synovial tissue (table 1). ${ }^{17} 20$ These findings suggest that further investigations are required to define, in particular, the intra-articular inflammatory response in AS, including the Th1/Th2 balance.

The mRNA expression levels in the synovial tissue of patients with RA were compared with those of patients with AS $(n=2)$, uSpA $(n=10)$, and PsA $(n=2)$. It was reported that all the patients with spondyloarthropathy had reduced IFN $\gamma$ mRNA levels compared with patients 
with RA. ${ }^{29}$ Although together the data are suggestive of an impaired or absent Thl cytokine production in joints of patients with AS, more data need to be collected to confirm this suggestion. The assumption that AS is characterised by a Th2 cytokine profile, ${ }^{22}{ }^{30}$ however, is not scientifically sound. Increased production of IL4 has not been shown in AS. In two patients with AS it was even found that IL4 mRNA expression in the synovial tissue was lower than the IL4 expression in patients with RA, which in many studies has been shown to be very low. ${ }^{29}$

To gain further insight in the role of the Th1/Th2 balance in patients with AS, Rudwaleit et al studied the impact of Th2 driven atopy on AS in comparison with the impact of atopy on RA. ${ }^{13}$ The reverse-the effects of RA and AS on atopy-was also studied. The atopyinduced amelioration of disease severity in patients with RA was not seen in patients with AS.

\section{"Atopic diseases are not decreased in patients with $\mathrm{AS}^{\prime \prime}$}

Also, the decreased prevalence of atopic disorders, such as hay fever, asthma, and atopic dermatitis, in patients with RA was not found in patients with AS (table 2). Instead, the prevalence of atopy in patients with AS $(24.6 \%)$ was slightly increased compared with healthy controls (20.7\%). This difference is even more pronounced (23.4\% in AS $v 15.8 \%$ in controls, $48 \%$ increase) when the bias introduced by latex allergies is taken into account, because these were observed more often in the control group which consisted of hospital workers who are more often exposed to latex $(4.9 \%$ for controls $v$ $1.2 \%$ for AS).

These data suggest that AS is not a disease in which Thl predominates because atopic responses are not inhibited by AS. Furthermore, patients with AS are not likely to benefit from Th2 activity because atopy does not reduce the symptoms of AS.

\section{Conclusions and discussion}

Low Thl activity in patients with AS is supported by the lower proinflammatory cytokine production (observed as lower TNF $\alpha$ and ILl $\beta$ levels) in AS compared with patients with RA. This is in line with the less aggressive form of arthritis seen in patients with AS. The slightly increased prevalence of atopy in AS might indicate that AS is associated with a predominant humoral immunity. Although there is no evidence for a typical Th2 response, joint inflammation in patients with AS may be associated with humoral responses. In patients with rheumatic fever, arthritis has been shown to be induced by such a response, dependent on bacteria-induced cross reactive autoantibodies to joint antigens. ${ }^{31}$ In a group of patients with spondyloarthropathies, including those with AS, IL10 serum levels, which can stimulate humoral responses and inhibit Thl activity, correlated with disease activity. ${ }^{32}$ Although no separate data on patients with AS were given in this study it can be speculated that IL10-induced antibody production in AS (as, for example, in rheumatic fever) is not inhibited by Th2 activity but may even be stimulated. The association with bacterial infection is supported by the HLA-B27 predisposition found in AS and ReA (approximately $90 \%$ and $50 \%$ of the patients, respectively). The intraarticular presence of bacteria in ReA correlates with joint inflammation. If this is true for AS as well, effective clearance may require Thl-induced immunity and might be counteracted by Th2 activity.

The different effects of atopy-induced Th2 predominance on RA and AS raise the question as to what the impact of this Th2 mediated immune deviation is on other forms of arthritis such as ReA. The presence of Th2 activity in ReA has been thought to contribute to the remitting form of this arthritis in contrast with patients with RA who do not have a Th2 response and who have chronic arthritis. ${ }^{33}$ However, based on more recent studies it has been suggested that Th2 responses (together with IL10 production), which are detected in patients with ReA, may prevent effective clearance of arthritis-inducing bacteria and sustain the arthritis. ${ }^{24}$ The role of Th2 activity in this infection-induced arthritis becomes even more uncertain when one takes into account the fact that clearance of some bacteria (for example, Borrelia burgdorferi in Lyme arthritis) seems to require Th2-induced immunity. ${ }^{34}$ Studying the impact of atopic disorders on disease activity in patients with ReA may provide an insight into the role of Th2 polarisation in this arthritic response.

Together, the effect of Th2 mediated atopic disorders on RA and other Thl mediated (autoimmune) inflammatory conditions suggests a potential beneficial role of Th2 induction in these patients. In contrast, a similar approach seems less useful in the treatment of patients with AS. This emphasises the diversity of the different arthropathies and the importance of documenting the actual intraarticular inflammatory responses in relation to clearly defined disease characteristics of the separate arthritic forms. Investigation of the impact of naturally occurring Th2 mediated immune deviation on the various forms of arthritis may prove to be a tool to clarify the role of Th1/Th2 balances in these diseases. It might also clarify whether Th2 mediated diseases like atopic disorders have a favourable impact on the prevalence of several arthritic conditions, including RA, because this so far has not been convincingly proved. Because of the prevalence of the arthritic conditions, collaborative efforts are required because large numbers of patients need to be included.

Ann Rheum Dis 2002;61:951-954

\section{Authors' affiliations}

J A G van Roon, J W J Bijlsma, UMC Utrecht, The Netherlands

Correspondence to: $\operatorname{DrJ}$ A G van Roon, Heidelberlaan 100, F02.127. Utrecht 3584 CX, The Netherlands; i.vanroon@azu.nl

\section{REFERENCES}

1 Mosmann TR, Sad S. The expanding universe of T-cell subsets: Th1, Th2 and more. Immunol Today 1996; 17:138-46.

2 Taams LS, Smith J, Rustin MH, Salmon M, Poulter LW, Akbar AN. Human anergic/suppressive CD4(+)CD25(+) T cells: a highly differentiated and apoptosis-prone population. Eur J Immunol 2001;31:112231 .

3 Weiner HL. Induction and mechanism of action of transforming growth factor-beta-secreting Th3 regulatory cells. Immunol Rev 2001;182:207-14.

4 Dolhain RJ, van der Heiden AN, ter Haar NT, Breedveld FC, Miltenburg AM. Shift toward T lymphocytes with a T helper 1 cytokine-secretion profile in the joints of patients with rheumatoid arthritis. Arthritis Rheum 1996;39:1961-9.

5 Gratacos J, Collado A, Filella X, Sanmarti R, Canete J, Llena J, et al. Serum cytokines (IL-6, TNF-alpha, IL-1 beta and IFN-gamma) in ankylosing spondylitis: a close correlation between serum IL-6 and disease activity and severity. Br J Rheumatol 1994;33:927-31.

6 Yudoh K, Matsuno H, Nakazawa F, Yonezawa T, Kimura T. Reduced expression of the regulatory CD4+ T cell subset is related to Th1/Th2 balance and disease severity in rheumatoid arthritis. Arthritis Rheum 2000:43:617-27.

7 Mulherin D, Fitzgerald $O$, Bresnihan B. Synovial tissue macrophage populations and articular damage in rheumatoid arthritis. Arthritis Rheum 1996;39:115-24.

8 van Roon JA, Lafeber FP, Bijlsma JW. Synergistic activity of interleukin-4 and interleukin-10 in suppression of inflammation and joint destruction in rheumatoid arthritis. Arthritis Rheum 2001:44:3-12.

9 Allanore $\mathrm{Y}$, Hilliquin P, Coste J, Renoux M, Menkes CJ. Decreased prevalence of atopy in rheumatoid arthritis. Lancet 1998;351:497.

10 O'Driscoll BR, Milburn HJ, Kemeny DM, Cochrane GM, Panayi GS. Atopy and rheumatoid arthritis. Clin Allergy 1985; 15:547-53.

11 Reckner OA, Skogh T, Wingren G. Comorbidity and lifestyle, reproductive factors, and environmental exposures associated with rheumatoid arthritis. Ann Rheum Dis 2001;60:934-9.

12 Verhoef CM, van Roon JA, Vianen ME, Bruijnzeel-Koomen CA, Lafeber FP, Bijlsma JW. Mutual antagonism of rheumatoid arthritis and hay fever; a role for type 1/type 2 T cell balance. Ann Rheum Dis 1998;57:275-80.

13 Rudwaleit $M$, Andermann $B$, Alten $R$, Sörensen H, Listing J, Zink A, et al. Atopic disorders in ankylosing spondylitis and rheumatoid arthritis. Ann Rheum Dis 2002;61:968-74. 
14 Douek IF, Leech NJ, Gillmor HA, Bingley PJ, Gale EA. Children with type-1 diabetes and their unaffected siblings have fewer symptoms of asthma. Lancet 1999;353:1850.

15 Oro AS, Guarino TJ, Driver R, Steinman L, Umetsu DT. Regulation of disease susceptibility: decreased prevalence of lgE-mediated allergic disease in patients with multiple sclerosis. J Allergy Clin Immunol 1996:97:1402-8.

16 Shirakawa T, Enomoto T, Shimazu S, Hopkin JM. The inverse association between tuberculin responses and atopic disorder. Science 1997;275:77-9.

17 Braun J, Bollow M, Neure L, Seipelt E, Seyrekbasan F, Herbst $\mathrm{H}$, et al. Use of immunohistologic and in situ hybridization techniques in the examination of sacroiliac joint biopsy specimens from patients with ankylosing spondylitis. Arthritis Rheum 1995;38:499-505

18 al Janadi N, al Dalaan A, al Balla S, Raziuddin S. CD4+ T cell inducible immunoregulatory cytokine response in rheumatoid arthritis. J Rheumatol 1996;23:809-14.

19 Haddad A, Bienvenu J, Miossec P. Increased production of a Th2 cytokine profile by activated whole blood cells from rheumatoid arthritis patients. J Clin Immunol 1998; 18:399-403.

20 Rudwaleit M, Siegert S, Yin Z, Eick J, Thiel A, Radbruch A, et al. Low T cell production of TNF $\alpha$ and IFN $\gamma$ in ankylosing spondylitis: its relation to HLA-B27 and influence of the TNF-308 gene polymorphism. Ann Rheum Dis 2001;60:36-42.

21 van Roon JA, Verhoef CM, van Roy JL, Gmelig-Meyling FH, Huber-Bruning O, Lafeber
FP, et al. Decrease in peripheral type 1 over type $2 \mathrm{~T}$ cell cytokine production in patients with rheumatoid arthritis correlates with an increase in severity of disease. Ann Rheum Dis 1997:56:656-60.

22 Baeten D, Van Damme N, Van Den BF, Kruithof E, De Vos M, Mielants H, et al. Impaired Th 1 cytokine production in spondyloarthropathy is restored by anti-TNF $\alpha$. Ann Rheum Dis 2001:60:750-5.

23 Braun J, Yin Z, Spiller I, Siegert S, Rudwaleit $M$, Liu $L$, et al. Low secretion of tumor necrosis factor alpha, but no other Th1 or Th2 cytokines, by peripheral blood mononuclear cells correlates with chronicity in reactive arthritis. Arthritis Rheum 1999;42:2039-44

24 Yin Z, Braun J, Neure L, Wu P, Liu L, Eggens $U$, et al. Crucial role of interleukin-10/ interleukin-1 2 balance in the regulation of the type $2 \mathrm{~T}$ helper cytokine response in reactive arthritis. Arthritis Rheum 1997;40:1788-97.

25 Austrup F, Vestweber D, Borges E, Lohning $M$, Braver R, Herz U, et al. P- and E-selectin mediate recruitment of T-helper-1 but not T-helper-2 cells into inflammed tissues. Nature 1997:385:81-3.

26 Maurice $M M$, van der Graaff $W L$, Leow A, Breedveld FC, van Lier RA, Verweij CL. Treatment with monoclonal anti-tumor necrosis factor alpha antibody results in an accumulation of Th 1 CD4+ T cells in the peripheral blood of patients with rheumatoid arthritis. Arthritis Rheum 1999;42:2166-73.

27 Cope AP, Londei M, Chu NR, Cohen SB, Elliott M, Brennan FM, et al. Chronic exposure to tumor necrosis factor (TNF) in vitro impairs the activation of T cells through the T cell receptor/CD3 complex; reversal in vivo by anti-TNF antibodies in patients with rheumatoid arthritis. J Clin Invest 1994;94:749-60.

28 Hermann E, Sucke B, Droste U, Meyer zum Buschenfelde KH. Klebsiella

pneumoniae-reactive T cells in blood and synovial fluid of patients with ankylosing spondylitis. Comparison with HLA-B27+ healthy control subjects in a limiting dilution study and determination of the specificity of synovial fluid T cell clones. Arthritis Rheum 1995;38:1277-82.

29 Canete JD, Martinez SE, Farres J, Sanmarti R, Blay M, Gomez A, et al. Differential Th1/Th2 cytokine patterns in chronic arthritis: interferon gamma is highly expressed in synovium of rheumatoid arthritis compared with seronegative spondyloarthropathies. Ann Rheum Dis 2000;59:263-8.

30 Dayer JM, Krane SM. Anti-TNF-alpha therapy for ankylosing spondylitis-a specific or nonspecific treatment? N Engl J Med 2002;346: 1399-400.

31 Baird RW, Bronze MS, Kraus W, Hill HR, Veasey LG, Dale JB. Epitopes of group A streptococcal $M$ protein shared with antigens of articular cartilage and synovium. J Immunol 1991;146:3132-7.

32 Claudepierre P, Rymer JC, Chevalier X. IL-10 plasma levels correlate with disease activity in spondyloarthropathy. J Rheumatol 1997;24:1659-61

33 Simon AK, Seipelt E, Sieper J. Divergent T-cell cytokine patterns in inflammatory arthritis. Proc Natl Acad Sci USA 1994;91:8562-6.

34 Keane-Myers A, Nickell SP. Role of IL-4 and IFN-gamma in modulation of immunity to Borrelia burgdorferi in mice. J Immunol 1995; 155:2020-8. 